\section{Bubbling up}

ET58 has been a challenging issue to edit and structure, and in the end it dictated its own shape. Instead of the usual six main articles, all about the same length, with their accompanying raft of supporting features of a more or less predictable kind, we have three rather special features:

- The sixth and final part of the Cambridge University Press Langscape Project, the brainchild of Pam Peters of Macquarie University, together with her report on the results of the third part (all of which we have been handling entirely electronically between Sydney and Cambridge).

- A special double feature from David Crystal on both the World English scene and the demands which its complexity and variety are now imposing on English language teaching everywhere. The first part we have therefore called 'Language matters' and the second 'Teaching matters'.

- A challenging piece by the linguist Marko Modiano in Sweden, which we have complemented with invited comments from six leading observers of English today, and which we hope will stimulate further discussion on a key issue: the future international standing of competent non-native users of English.

These three features necessarily overlap, in a time of vast language change on every continent and in every ocean. It seems to me that this communicative upheaval - and its effect on what we call 'English' - is at least as great as any of the vast events in the history of this language complex, ranking with (and dwarfing?) 1066, the Tudor-Jacobean diaspora, the pressure for a standard in the time of Johnson, the Industrial Revolution, the heyday of the British Empire, and the rise to pre-eminence of the United States.

All of which is relevantly flanked by the usual news, views, and reviews, which in this issue range from wombats on the Internet through the Billy Bunter books, changes in British pronunciation, and the slack style of American industrial writers to a comment of my own on the marked impact of California on the language everywhere. This article points to a new well of English - defiled or reinvigorated: the choice is yours - which has been bubbling up in Silicon Valley, in the state's pullulating therapy culture, and maybe most powerfully of all in Hollywood, where the vast and boldly unending Star Trek saga plays a significant role.

Tom McArthur

The editorial policy of English Today is to provide a focus or forum for all sorts of news and opinion from around the world. The points of view of individual writers are as a consequence their own, and do not reflect the opinion of the editorial board. In addition, wherever feasible, ET generally leaves unchanged the orthography (normally British or American) and the usage of individual contributors, although the editorial style of the journal itself is that of Cambridge University Press.
C Cambridge University Press 1999 No contents may be reproduced by any means without the permission of Cambridge University Press.

English Today (ISSN 0266-0784) is a quarterly.

\section{Publisher:}

Cambridge University Press,

The Edinburgh Building, Cambridge CB2 2RU, United Kingdom.

Telephone (01223) 312393 Email: English_Today@cup.cam.ac.uk

Subscriptions: the current annual subscription price for four issues for libraries and institutions is $\mathbf{f 5 7}$ outside North America; $£ 29$ for individuals; $\mathrm{f} 22$ for students and the retired. Prices include delivery by air where appropriate. Apply to Jane Crossland at the above address.

Advertising Sales: write to the Advertising Promoter at the above address.

USA, CANADA AND MEXICO: Publisher:

Cambridge University Press, 40 West 20th Street, New York, NY 10011-4211, USA.

Telephone (212) 9243900.

Subscriptions: the current annual subscription price in USA, Canada and Mexico for libraries and institutions is $\$ 90 ; \$ 46$ for individuals; $\$ 35$ for students and the retired. Apply to Joseph D.

Hranek at the above address. Advertising Sales: write to the Advertising Coordinator at the above address.

Periodicals postage paid at New York, NY and at additional mailing offices.

POSTMASTER: send address changes in USA, Canada and Mexico to English Today, Cambridge University Press, 110 Midland Avenue, Port Chester, New York, NY 10573-4930, USA.

Japanese prices for institutions are available from Kinokuniya Company Ltd, P.O. Box 55, Chitose, Tokyo 156, Japan.

Letters to the Editor: write to Dr Tom McArthur, Editor, English Today, 22-23 Ventress Farm Court, Cherry Hinton Road, Cambridge CB1 4HD, UK. Tel 01223245934 Fax 01223241161.

Email: Scotsway@aol.com

This journal is included in the Cambridge Journals Online service which can be found at wuw.journals.cup.org. For further information on other Press titles access www.cup.cam.ac.uk or wnw.cup.org.

Printed in the United Kingdom by the University Press, Cambridge 